\section{Gastric metastasis of a renal cell carcinoma presenting as a polypoid mass}

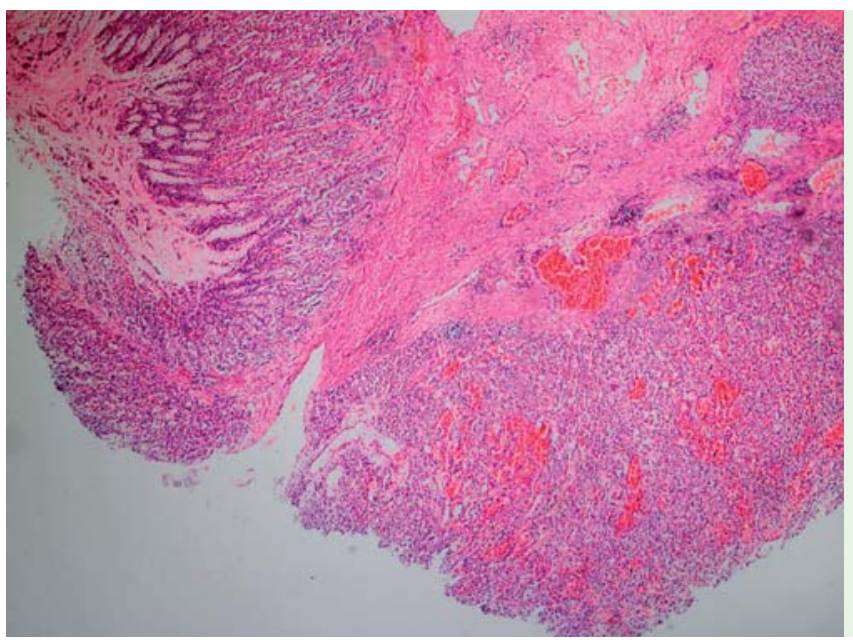

Fig. 1 A 7-cm polypoid mass was resected from the gastric corpus of a 59-year-old man who had undergone right radical nephrectomy for renal cell carcinoma 4 years previously. An infiltrative hypervascular lesion is seen adjacent to hyperplastic epithelium.

Renal cell carcinomas (RCCs) account for approximately $3 \%$ of adult malignancies. More than $50 \%$ of RCCs are detected incidentally, and in approximately one-third of patients, RCCs have metastasized at the time of initial diagnosis [1]. The sites of metastasis include the lungs (75\%), soft tissues (36\%), bones (20\%), liver (18\%), skin ( $8 \%)$, and central nervous system (8\%) [2]. Gastric metastases of RCC are extremely rare, with only 23 cases reported in the literature [3]. We describe here a case of metastatic RCC presenting as a polypoid mass $7 \mathrm{~cm}$ in diameter.

A 59-year-old man was admitted to our hospital with weight loss and melena. He had undergone a right radical nephrectomy for a diagnosis of RCC 4 years earlier. On endoscopic examination, an ulcerated polyp $7 \mathrm{~cm}$ in diameter was noted in the corpus of the stomach. The patient underwent a partial gastrectomy, and a gastric adenocarcinoma was diagnosed. In the resected specimen, the tumor, which measured $7 \mathrm{~cm}$, was a polypoid mass with an ulcerative growth pattern and some hemorrhagic areas. Based on the morphologic ( Fig. 1, Fig.2) and immunohistochemical (๑ Fig.3, Fig.4) features of the lesion, we diagnosed metastatic clear cell RCC.

The stomach is an unusual site of metastasis, even in autopsy series. Gastric metastases are most often from carcinomas of the lung and breast and from malignant melanomas [4]. Gastric metastases of RCC are very rare.

According to the literature, most gastric metastases of RCCs occur in male patients.
The mean time to metastasis is nearly 7 years ( $0-20$ years). Gastric metastases are more common in the body of the stomach and tend to be a solitary mass or an ulcer resembling a primary gastric tumor [5].

Patients with RCC who undergo nephrectomy should be carefully followed up with imaging methods. The early treatment of RCC metastases to distant organs can be important for patient survival. The diagnosis of metastatic RCC should be considered if a patient has a history of RCC with clear cell morphology of the tumor cells.

Endoscopy_UCTN_Code_CCL_1AB_2AD_3AB

Competing interests: None

\section{Emrah Kumcu, Mehmet Gönültas, Hatǐce Ünverdǐ, Sema Hücüimenoğlu}

Department of Pathology, Ankara Education and Research Hospital, Ankara, Turkey

\section{References}

1 Tiwari P, Tiwari A, Vijay M et al. Upper gastro-intestinal bleeding - rare presentation of renal cell carcinoma. Urol Ann 2010; 2: $127-129$

2 Maldazys JD, deKernion JB. Prognostic factors in metastatic renal carcinoma. J Urol 1986; 136: 376-379

3 Sakurai K, Muguruma K, Yamazoe $S$ et al. Gastric metastasis from renal cell carcinoma with gastrointestinal bleeding: a case report and review of the literature. Int Surg 2014; 99: 86-90

4 Pollheimer MJ, Hinterleitner TA, Pollheimer $V S$ et al. Renal cell carcinoma metastatic to the stomach: single-centre experience and literature review. BJU Int 2008; 102: 15 - 19

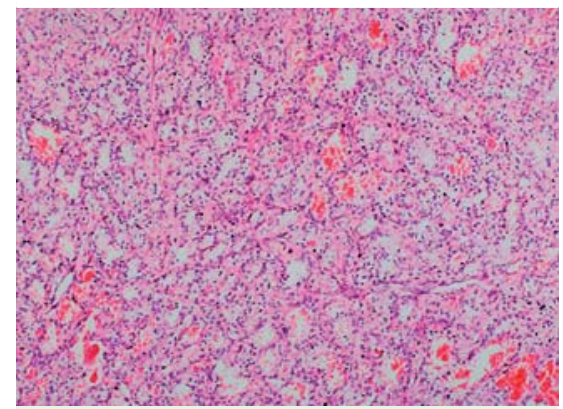

Fig. 2 Numerous sinusoid-like vascular channels are seen in the stroma of the tumor, and the tumor cells contain clear cytoplasm.

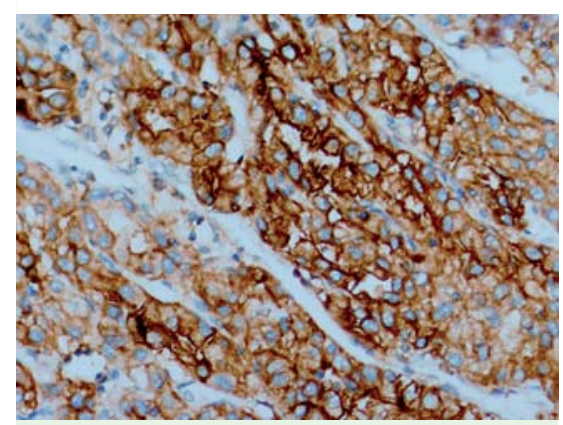

Fig. 3 CD10 positivity is observed in the tumor cells.

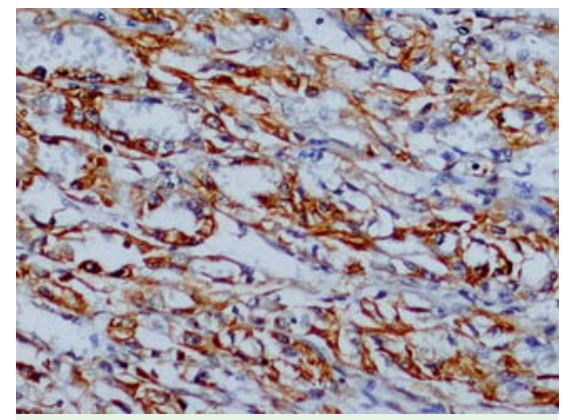

Fig.4 Vimentin positivity is observed in the tumor cells.

5 Xu J, LatifS, Wei S. Metastatic renal cell carcinoma presenting as gastric polyps: a case report and review of the literature. Int J Surg Case Rep 2012; 3: 601 -604

\section{Bibliography}

Dol http://dx.doi.org/

10.1055/s-0034-1377550

Endoscopy 2014; 46: E464

(c) Georg Thieme Verlag KG

Stuttgart · New York

ISSN 0013-726X

\section{Corresponding author}

\section{Emrah Kumcu, MD}

Department of Pathology

Ankara Education and Research Hospital

Ulucanlar Ankara

Turkey 06010

Fax: +90-312-5953640

emrahkumcu85@hotmail.com 